\title{
Inese Runce
}

\section{LATGALES TERITORIĀLĀ IDENTITĀTE GLOKALIZĀCIJAS UN GLOBALIZĀCIJAS KRUSTCEĻOS}

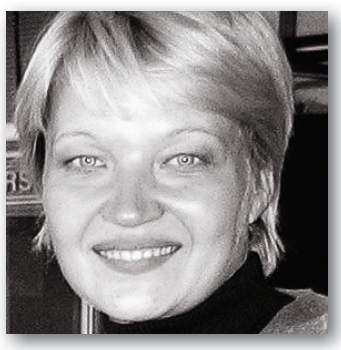

Raksts atspoguļo Latgales teritoriālās identitātes veidošanas un konstruēšanas procesus globalizāacijas un glokalizācijas procesu ietekmē pēdējo 20 gadu laikā. Autore piedāvā isu ieskatu globalizācijas un glokalizäcijas procesu krustpunktos un nacionālo valstu idejas vājināšanās tendencēs müsdienu pasaulē. Latgales teritoriāalās identitātes veidošanās izaicinājumi tiek aplūkoti atseviškos posmos pēdējo divdesmit gadu laikā un augšminēto pasaules sociālpolitisko procesu (globalizācija, glokalizācija, nacionālā valsts un ekonomiskā krīze, jaunas nacionālās identitātes konstruēšana) šşērsgriezumā.

\section{THE TERRITORIAL IDENTY OF LATGALE IN THE CROSSROADS OF GLOBALIZATION AND GLOCALIZATION}

The aim of this paper is to analyze the processes of formation of Latgale's territorial identity during the age of globalization in the last 20 years. Research was carried out using the latest data of qualitative research of the Institute of Philosophy and Sociology of University of Latvia (the thematic research of Latvian Science Council's project "Political development of the nation's self-confidence after restoration of Latvian independence: Trends and Factors," head of project: Inese Runce, 2009-2012) and the latest theoretical insights of territorial identity construction processes under the impact of globalization and glocalization.

On the basis of analysis of the socio-political processes and the experience of other countries, it must be emphasised that the placemaking is an important political process, not only at national but also at sub-regional level. Regional authorities should be able to offer a specific political vision, not only to the national power authorities, but also to the main bearers of regional identity - the people in regions.

As it is shown by the recent studies, during the past 20 years in Latvia, the regional identity manifests itself only in Latgale where it is alive and vibrant, and the care and preservation and making of identity comes directly from the very bearers of this identity. Regional authorities, in collaboration with local NGOs, experts on culture, etc. must also contribute to the internal integration of the region, where each municipality and each form of local identity has its own recognized place and function, creating diverse forms of sustainable regional communities and regional identities. Regional identity is not exclusive and is able to unite different religious, ethnic, linguistic groups in a single whole entity.

Over the past twenty years the process of formation of Latgale regional identity can be divided into three stages:

1. 90 s of $20^{\text {th }}$ century - the stage of denial of regional identity. In this decade the preservation and construction of Latgale regional identity is carried out only by few individuals or interest groups: writers, researchers, artists, local intellectuals who are mainly based in the circles of local intellectuals at Rezekne University College, as well as indirectly Latgale Research Institute of Daugavpils University;

2. The first decade of 2000s - a gradual increase of awareness of regional identity. During the period this has been a gradual growth of awareness of regional identity and its 
development process. "Latgale radio", Latgalian music groups are being launched, also the extensive scientific and political debate on the status of Latgale language started, socio-linguistic research projects initiated and a new non-governmental organizations established, the first portals in Latgalian as well the new initiative of regional municipalities are being launched;

3. 2010 to 2013 - analyzing the last three years of political and intellectual life trends, it can be argued that a qualitatively new stage in the recognition of regional identity and its construction process has been created: current political debate before and after the elections of 11th Saeima and the language referendum, discussions on the role of Latgalian as regional language, the National Development plan (NDP), development of the structural budget plans. However, it is clear that those spring sprouts must be protected, due to the fact that the strong centralizing tendencies in the Latvian political culture still exist.

Pētījuma mērḳis ir analizēt Latgales teritoriālās identitātes veidošanās procesus globalizācijas un glokalizācijas procesu ietekmē pēdējos divdesmit gados. Raksts ir tapis, izmantojot jaunākos Latvijas Universitātes Filozofijas un sociologiijas institūta kvalitatīvos pētījumus (LZP tematiskais pētījumu projekts „Politiskās nācijas pašapziņas veidošanās pēc Latvijas neatkarības atjaunošanas: tendences un faktori", 2009.-2012., projekta vadītāja - Inese Runce) un teorētiskās atziņas par teritoriālās identitātes konstuēšanas procesiem globalizācijas un glokalizācijas procesu ietekmē.

Mūsdienu Eiropā, ņemot vērā tehnolog̣iju attīstību un strauju paralēlās digitālās telpas veidošanos un tīklošanos, federalizācijas idejas attīstību, globalizācijas procesu pieaugumu, kā arī ekonomiskās krīzes radītās sekas, ir redzamas nepārprotamas nacionālās valsts idejas vājināšanās tendences. Globalizācijas tendences modernajā pasaulē ir veicinājušas interesi par regiionālajām kultūrām, radot un aizsākot pretēju sociopolitisku, kultūras un intelektuālo tendenci - glokalizāciju. Globalizācijas un glokalizācijas procesi ir nesaraujami saistīti. Kā atbildi uz kultūras globalizācijas izaicinājumiem sabiedrības un kopienas nereti izvēlas glokalizāciju, un tieši glokalizācija ir visbiežāk sastopamā atbilde uz jebkura veida politiskajiem un ekonomiskajiem izaicinājumiem un sabiedrības sociālo transformāciju. (Ho Kin Tong \& Lin Hong Cheung 2011: 56-68)

Kultūras un valodu ziṇā atšķirīgas teritorijas Eiropā un arī pārējā pasaulē ir pastāvējušas ilgi pirms nacionālo valstu veidojumiem. Modernās nacionālās valsts modelis ir apmēram 500 gadus sens, bet jēdziens nācija ir vēl jaunāks, tas radies Eiropā pēc Franču revolūcijas 18. gs. beigās. (Kaplan, Herb 1999: 3)

Jaunā gadu tūkstoša sākumā globalizācijas procesi ir dramatiski palielinājuši vajadzību pēc sociālajiem tīkliem, taču līdz ar sabiedrības individualizāciju sociālie tīkli ir mainījuši ar̄i cilvēka sociālo identitāti. Mazās tradicionālās kopienas (organizācijas, draudzes, darba kolektīvi u. c.), kas ar daudzām saitēm vienoja indivīdus gadsimtiem ilgi, pamazām zaudē savu nozīmi vai arī pazūd. Mūsdienās indivīdus šīs kopienas vēl spēj vienot, taču tās kḷūst atšḳeltas viena no otras, jo cilvēki nemitīgi izvēlas, ar ko ir vērts komunicēt. Saites, kas vieno šīs jaunās digitālās indivīd-centrētās kopienas, ir daudz vājākas un ātrāk nomaināmas nekā tradicionālās. Šādā situācijā stabilās kolektīvās kopienas ir sadalījušās vairākās viegli transformējamās, īslaicīgajās un individuālajās kopienās. (Terlow 2009: 454)

Ipašs spilgti nacionālo valstu krīzes ideja ir manāma federālo Eiropas valstu iekšpolitiskajos procesos, kā, piemēram, Skotijā, Basku zemē un Katalonijā. Savukārt nacionālo valstu reǵionos ir manāms spēcīgs teritoriālās identitātes pašapziņas pieaugums Dienvidigaunijā (setu un viru), Somijā (Lapzeme, Ālandu salas), Zviedrijā (Skone, Gotlande 
u. c.), līdzīga veida procesi ir vērojami arī Latgalē. Teritoriālās identitātes nozīmes pieaugums politiskajās un intelektuālajās diskusijās visai bieži tiek saistīts ar globalizāciju un nācijas valsts lomas mazināšanos, taču tie paši procesi, kas padara reǵionālo identitāti svarīgu, spēj to arī graut, īpaši tajās valstīs, kur šī forma ir bijusi visai vāja. (Terlow 2009: 452)

Pēdējo 20 gadu laikā, ǵeometriskā progresijā pieaugot globalizācijas tendencēm, tikpat strauji ir pieaugusi interese par reǵionālajām un lokālajām kultūrām, kā arī šo teritoriju iekšējā vitalitāte. Reǵionālajai identitātei nacionālā valstī ir raksturīga noteikta teritorija, tai var būt atšksirīga valoda vai valodas dialekts, reliğija vai konfesionalitāte, sociālās pazīmes vai administratīvā tradīcija, kā arī kopējas problēmas.

Jēdziens "glokalizācija" parādījās 20. gs. 80. gadu beigās Japānā biznesa vidē kā pretmets globalizācijas procesam, uzsverot vietējās biznesa vides īpatnības un specifiku. Glokalizācijas koncepts strauji izplatījās visā pasaulē un tika izmantots kultūrā, zinātnē, medijos, izglītîbā, ka arī reǵionālistikā un teritoriālo identitāšu pētniecības procesā, kḷūstot par savdabīgu, bet l̦oti iedarbīgu intelektuālo un emcionālo līdzekli atvešinātības procesa pārvarēšanā, revitalizējot un aktualizējot reǵionālo un lokālo kultūru eksistenci. Socioloǵijā jēdziens „glokalizācija” tiek aprobēts un zinātniski plaši pielietots jau 20. gs. 90. gadu sākumā.

Paradoksāli, bet globalizācijas un glokalizācijas procesi ir nesaraujami saistīti. Britu sociologs Antonijs Gidenss uzskata, ka glokalizācija ir kultūras identitāšu atdzimšanas iemesls dažādās pasaules malās. (Giddens 2000: 31) Lokālais tiek veidots kā dominējošo sociālo procesu pretstats un emocionāla atbilde visam globālajam. (Khondker 2004: 5)

Glokalizācijai un globalizācijai ir četri tieši saskares punkti:

1. Dažādība ir sociālās dzīves esence.

2. Globalizācija nespēj dzēst visas atšķirības.

3. Vēstures un kultūras autonomija konkrētai grupai, sabiedrībai, kopienai vai nācijai nodrošina unikalitātes sajūtu.

4. Glokalizācija ir atbrīvošanās no bailēm, ka globalizācija ir kā paisuma vilnis, kas aizslauka visas atškirīibas. (Khondker 2004: 5)

Teritoriālajai identitātei piemīt jēgpilna nozīme, kas ir sociāli konstruēta, bet nav statiska, gluži kā cilvēki, kam piemīt daudzveidīgas identitāšu formas. 20. gs. 70. gados ǵeogrāfijas zinātnes humānistu skolas sekotāji uzsāka intelektuālas debates par svarīgu fenomenoloǵisku jautājumu: kā cilvēki rada jēgpilnu pasauli un dzīvi? Šīs skolas pārstāvji postulēja, ka pastāv universāla un cilvēciska vajadzība - asociēt sevi ar konkrētu vietu jeb teritoriju. Kā vissvarīgākā un cilvēka eksistencei visnepieciešamākā vieta tika atzīta „mājas” vieta. Attiecības starp cilvēkiem un vietu vienmēr ir dialektiskas. Teritorija parasti ir cilvēku konstruēta, un tai ir piešksirtas daudzveidīgas nozīmes un identitāšu formas. Vietas veido cilvēkus un vinuu raksturus, līdz ar to var droši apgalvot, ka teritoriālā identitāte var tikt uztverta kā interaktīvs sadarbības rezultāts starp vietu un individuālās un kolektīvās esības formu daudzveidību, kas ietver sevī neizdzēšamu piederības sajūtu. Šis process pierāda, ka teritoriālā identitāte ir tēlaini veidota un nosaka to, kas mēs esam. (Torkington 2012: 75-76)

Līdz ar globalizācijas un glokalizācijas procesu pieaugumu pasaulē un jaunu reǵionālās identitātes pastāvēšanas izaicinājumu parādīšanos sociologi ir uzsvēruši nepieciešamību konstruēt vietas piederības sajūtu. Vietas konstruēšanas (place-making) prakses, ieskaitot semiotiskās un materiālās, ir dziḷi saistītas ar kultūras identitātes glokalizācijas projektu. (Torkington 2012: 72)

Latvijas valsts neatkarības atgūšana 1991. gadā sakrita ar jauno politisko, ekonomisko un kultūras situāciju pasaulē globalizācijas un glokalizācijas apstākḷlos. Neatkarību ieguvušajai Latvijas valstij un sabiedrībai bija ne tikai jārada jauna ekonomiskā sistēma un jauna nacionālā identitāte, bet arī jāspēj rast atbilde uz šo paralēlo procesu izaicinājumiem. 
Rietumeiropā un Austrumeiropā pastāv zināmas atšķirības un pieeja politiskajā attieksmē teritoriālajām identitātēm un vietas konstruēšanai. Rietumeiropā demokrātijas sistēmai ir dziḷākas tradīcijas un stabilākas saknes, gadu desmitos ir izveidojies balanss un dialogs starp varu un tautu, starp institūcijām, politiku un ekonomiku, centru un perifēriju. Taču reǵionālo identitāti pēdējā laikā ir vājinājusi nacionālo valstu krīze.

Austrumeiropā pēc aukstā kara beigām un komunisma sistēmas sabrukuma bija jārada jauna nacionālā identitāte, kas izrādījās pietiekami ilgs un sāpīgs process, jo nacionālais šķita ir tas, kas jāsargā, par ko jācīnās, un ne tikai pret dinastiālām valstu varām, bet arī pret pašu pilsoṇu vienaldzīgo attieksmi, kuru radīja nacionālais pašapziņas trūkums. (Batt, Wolczuk 2002: 1)

Centrālajā un Austrumeiropā, kur nacionālās identitātes bija konstruētas smagās cīṇās un par kurām 19.-20. gs. vēsturisko notikumu gaitā bija nemitīgi jācīnās, valstiskās robežas bija visjūtīgākais jautājums un nestabilākais faktors. Visām jaunajām neatkarību ieguvušajām valstīm bija jācīnās ne tikai par iekšējo un ārējo robežu konsolidāciju un jaunu kaimiņattiecību veidošanu, bet arī par reǵionālo un etnisko kopienu integrāciju vienā politiskā struktūrā, kā arī nereti jaunajās nacionālās identitātes konstrukcijās post-padomju sabiedrību intelektuāḷi un politiķi atgriezās padomju vai pirms kara politisko un ideologisko konstrukciju sliedēs. Kā piemēru var minēt Latvijas un Igaunijas valstu autoritāro režīmu prakses attiecībā uz reǵionālajām identitātēm: viru, setu un latgaliešu. Prakse pierādīja, ka pārejas posmā 20. gs. 90. gados šîs valstis un to sabiedrības cīnījās ar vēsturisko atminuu rēgiem, un reǵionālā politika, kas tobrīd tika veidota, tika konstruēta uz teritoriālo zaudējumu un ieguvumu vēsturiskās pieredzes bāzes. (Batt, Wolczuk 2002: 1)

Pēdējos 20 gadus teritoriālās identitātes veidošanās un vietas konstruēšanas procesu var iedalīt trijos posmos:

1. 20. gs. 90. gadi - reǵionālās identitātes noliegšanas posms. Šajā desmitgadē par latgaliešu identitātes saglabāšanu un attīstību cīnās tikai atsevišķi indivīdi vai interešu grupas: literāti, novadpētnieki, mākslinieki, vietējā inteliğence un intelektuāļi, kas galvenokārt tiešā vai pastarpinātā veidā bāzējas Rēzeknes Augstskolas paspārnē un humanitāro zinātnu inteliǵences lokā, kā arī pastarpināti Daugavpils Universitātes Latgales Pētniecības institūtā. Ja DU Latgales Pētniecības institūts norobežojās ar pētniecību, tad RA Humanitārajā fakultātē - jaunās paaudzes izglītošanu un latgaliskās kultūras un valodas aktualizāciju. Šo cīṇu par saglabāšanu varētu pat nosaukt par savdabīgu intelektuālo un zinātnisko pagrīdi un opozīciju: bez politiskā vai finansiālā atbalsta. Rēzeknes Augstskolas asociētā profesore un zinātñu prorektore Ilga Šuplinska, raksturojot šo posmu un tā ietekmi uz mūsdienām, secina: „Latgales lauki ir tukši. 90. gados bija pilni cilvēkiem, tagad - tukši. Te nav sajūtas, ka esi piederīgs šai valstij..." (Alberte 2012: 12)

2. 2000. gada pirmā desmitgade - pakāpenisks reǵionālās apziņas pieauguma posms un vietas konstruēšanas procesa aktīvs sākums. Šajā laikaposmā ir vērojams pakāpenisks reǵionālās apziņas un identitātes pieauguma un attīstības process. Šajā desmitgadē tiek dibināta „Latgales radio” (2005.gads), izveidotas latgaliski muzicējošas grupas (Borowa MC u.c.), gan Latgalē, gan Rīgā tiek organizētas plašas zinātniskas un politiskas diskusijas par latgaliešu valodas statusu un reǵionālo identitāti, uzsākti sociolingvistiskas pētījumu projekti, dibinātas jaunas nevalstiskās organizācijas, parādās pirmie interneta portāli latgaliešu valodā, uzsāktas jaunas vietējo pašvaldību iniciatīvas. Šo posmu noteikti varētu raksturot kā savdabīgu 21. gs. sākuma latgaliskās kultūras atdzimšanas posmu, kura priekšgalā bija vietējās latgaliešu inteliğences pārstāvji, kas neatlaidīgi cīnījās par reǵionālās identitātes saglabāšanu.

3. 2010.-2013. gads. Analizējot pēdējo pāris gadu politiskās un intelektuālās dzīves tendences, var apgalvot, $\mathrm{ka}$ ir vērojams kvalitatīvi jauns posms reǵionālās identitātes 
atż̄̌sanas un konstruēšanas procesā: Latvijā norit aktuālas politiskās diskusijas pirms un pēc 11. Saeimas vēlēšanām un valodas referenduma, diskusijas par latgaliešu valodas kā reǵionālās valodas nozīmi, Nacionālā Attīstības Plāna izstrāde, jauno Eiropas struktūrfondu budžeta plānojumi.

Balstoties uz sociālpolitisko procesu analīzi un citu valstu pieredzi, ir jāuzsver, ka vietas konstruēšana ir politiski svarīgs process ne tikai nacionālajā, bet arī iekšreǵionālajā līmen̄i. Reǵionālajām varas institūcijām ir jāspēj piedāvāt konkrēts politiskais redzējums ne tikai nacionālajām varas autoritātēm, bet arī pašiem šīs teritoriālās identitātes nesējiem vietējiem iedzīvotājiem. Kā redzams jaunākajos pētījumos, kas pēdējos gados tapuši Latvijāa, reğionālā identitāte mūsdienu Latvijas sabiedrībā manifestējas tikai Latgales teritorijā, turklāt tā ir dzīva un vitāla, un š̄is identitātes saglabāšanas un konstruēšanas ideja nāk no pašiem šīs identitātes nesējiem. Reǵionālās varas institūcijām sadarbībā ar vietējām nevalstiskajām organizācijām, kultūras ekspertiem u.c. ir jāveicina arī iekšējā reǵiona integrācija, kur katram pagastam un katrai lokālai identitātei ir sava atzīta vieta un funkcija, veidojot daudzveidīgu reǵionālo identitāšu formu un ilgtspējīgu reǵionālo kopienu, kas nav ekskluzīva un kas spēj vienot dažādu reliğisko, etnisko un lingvistisko grupu pārstāvjus vienā veselā.

\section{LITERATŪRA}

Alberte, Ieva (2012). Nav tikai dziedoši mērkaķi. Intervija ar Ilgu Šuplinsku. IR, 32(122), 9.-15. augusts. Batt Judy \& Wolczuk Kataryna (2002). Region, State and Identity in Central and Eastern Europe. London: Frank Cass Publishers Giddens, Anthony (2000). Runaway World. New York: Routledge.

Ho Kin Tong \& Lin Hong Cheung (2011). Cultural identity and language: a proposed framework for cultural globalisation and glocalisation. Journal of Multilingual and Multicultural Development. Volume 32, Issue 1. Taylor and Francis Online. http://www.tandfonline.com/doi/full/10.1080/01434632.2010.527344\#. UZAGULV0yHA(accessed May 7, 2013)

Kaplan David \& Herb Guntram (1999). Introduction: A Question of Identity// Nested identities. Nationalism, territory and scale. Oxford: Rowman\&Littlefield

Khondker, H.H. (2004). Glocalization as Globalization: Evolution of a Sociological Concept. Bangladesh e-Journal of Sociology. Vol. 1. No. 2. July, http://mukto-mona.net/Articles/habibul_haque/Globalization.pdf (accessed May 7,2013)

Terlouw, Kees (2009). Rescaling Regional Identities: Communicating Thick and Thin Regional Identities. Studies In Ethnicities \& Nationalism 9, No. 3, Academia Search Complete, EBSCOhost (accessed May 7, 2013), 452-462. Torkington, Kate (2012). Locating lifestyle migrants in the linguistic landscape. Mobilities. Vol. 7, No. 1,

Routledge, 71-92. 